\title{
Human herpesvirus type 8 variants in Kaposi's sarcoma before and after AIDS era
}

\author{
Maria Lina Tornesello ${ }^{1}$, Benon Biryahwaho ${ }^{2}$, Robert Downing ${ }^{2}$, Angelo Hatzakis ${ }^{3}$, Elvio Alessi ${ }^{4}$, Marco Cusini ${ }^{4}$, \\ Vincenzo Ruocco ${ }^{5}$, Giovanna Loquercio ${ }^{1}$, Edward Katongole-Mbidde², Luigi Buonaguro ${ }^{1}$, Franco M Buonaguro ${ }^{*}$ \\ From $12^{\text {th }}$ International Conference on Malignancies in AIDS and Other Acquired Immunodeficiencies \\ (ICMAOI) \\ Bethesda, MD, USA. 26-27 April, 2010
}

\section{Background}

Human herpesvirus 8 (HHV - 8) variants have been found heterogeneously distributed among human populations living in diverse geographic regions, but their differential pathogenicity in Kaposi's sarcoma (KS) development remains controversial. The aim of the present study was to analyze variations of HHV-8 genomes in tumor biopsies collected before and in the course of HIV epidemic (1971 - 2008), from patients with classic, iatrogenic, endemic as well as epidemic KS living in Africa, Europe, and North America.

\section{Materials and methods}

DNA samples have been extracted from cutaneous KS lesions of 68 patients living in Africa $(n=23$, Cameroon, Kenya and Uganda), Europe ( $\mathrm{n}=34$, Greece and Italy), and North America $(n=11)$. The identification and characterization of HHV-8 variants has been based on PCR amplification followed by direct nucleotide sequencing and phylogenetic analysis of the highly conserved ORF 26 and T0.7, the hypervariable ORF K1, as well as on the analysis of $\mathrm{P}$ and $\mathrm{M}$ alleles of the K14.1/15 locus.

\section{Results}

Among the 23 African samples, the majority of HHV-8 ORF 26 variants clustered with the subtype $R(n=12)$ and $B(n=5)$. Conversely, the viral sequences obtained from 45 European and North European tumors belonged mainly to subtype $\mathrm{A} / \mathrm{C}(\mathrm{n}=36)$. In general HHV-8 and K1 variant clustering paralleled that of ORF
26 and T0.7. Genotyping of the K14.1/15 loci revealed a large predominance of $\mathrm{P}$ subtype in all tumors.

\section{Conclusions}

Although the virus has genetic regions of high variability, approaching that of HIV-1 env gene, the HHV-8 subtypes remained stably distributed before and after the AIDS epidemic. These results suggest that the increased incidence of epidemic KS in low-incidence countries was not related to the spreading of high pathogenic HHV-8 variants, furthermore, suggest the presence of other cofactors in high risk KS countries pre-existing in pre-AIDS era [1].

\section{Acknowledgements}

We thank the late Prof SK Kyalwazi (Mulago Hospital, Kampala, Uganda), Prof VA Ngu (Univ., Yaounde, Cameroon), Prof B Safai (Sloan-Kettering/Memorial Hospital New York City, USA), Prof. N Mueller (Harvard School of Public Health, Boston, USA) and Prof G Giraldo (Natl Cancer Inst. Fond. Pascale, Napoli, Italy), for patients enrollement.

This article has been published as part of Infectious Agents and Cancer Volume 5 Supplement 1, 2010: Proceedings of the $12^{\text {th }}$ International Conference on Malignancies in AIDS and Other Acquired

Immunodeficiencies (ICMAOI). The full contents of the supplement are available online at http://www.biomedcentral.com/1750-9378/5?issue=S1.

\section{Author details}

${ }^{1}$ Molecular Biology and Viral Oncology \& AIDS Reference Centre, National Cancer Institute "Fondazione Pascale", Naples, Italy. ${ }^{2}$ Uganda Virus Research Institute, P.O. Box 49, Entebbe, Uganda. ${ }^{3}$ University of Athens, Athens, Greece. ${ }^{4}$ Institute of Dermatological Sciences, University and IRCCS Ospedale Maggiore, Milan, Italy. ${ }^{5}$ Department of Dermatology, Second University of Naples, Naples, Italy.

Published: 11 October 2010

*Correspondence: irccsvir@unina.it

${ }^{1}$ Molecular Biology and Viral Oncology \& AIDS Reference Centre, National Cancer Institute "Fondazione Pascale", Naples, Italy 


\section{Reference}

1. Tornesello ML, Biryahwaho B, Downing R, Hatzakis A, Alessi E, Cusini M, et al: Human herpesvirus type 8 variants circulating in Europe, Africa and North America in classic, endemic and epidemic Kaposi's sarcoma lesions during pre-AIDS and AIDS era. Virology 2010, 398:280-289.

doi:10.1186/1750-9378-5-S1-A37

Cite this article as: Tornesello et al: Human herpesvirus type 8 variants

in Kaposi's sarcoma before and after AIDS era. Infectious Agents and

Cancer 2010 5(Suppl 1):A37.

Submit your next manuscript to BioMed Central and take full advantage of:

- Convenient online submission

- Thorough peer review

- No space constraints or color figure charges

- Immediate publication on acceptance

- Inclusion in PubMed, CAS, Scopus and Google Scholar

- Research which is freely available for redistribution

Submit your manuscript at www.biomedcentral.com/submit

() BioMed Central 